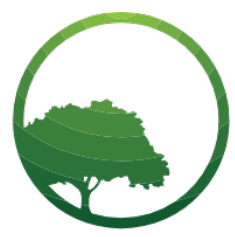

Business \& Social Science IJRBS

\section{Research in Business and Social Science}

IJRBS Vol 8 No 4, ISSN: 2147-4478

Contents available at www.ssbfnet.com/ojs

\title{
A Critical Assessment on Bank Valuation in Existing Literature in the Last Decade
}

\author{
Antonio J. Dayag
}

University of Sto. Tomas (UST), Espaňa, Manila

\section{Fernando Trinidad}

University of Sto. Tomas (UST) Graduate School, Espaňa, Manila

\begin{abstract}
This paper examines vast literature covering bank valuation practices, frameworks, and various factors that impact bank valuation. Researches on bank valuation covering the last 10 [ten] years were made, and there appear to have a certain level of conservatism on how to measure value of banks. This could be due to the recent global financial crisis, and what is common among the studies was, discourage banks from taking on additional risks. Different factors impact bank valuation and it depends on country and economic circumstances, including banking regulations and internal governance. Various bank valuation frameworks were also added from extensive researches gathered. The literature review also identified nine [9] variables that impact bank valuation, seven [7] of which are bank-specific attributes, one [1] is regulation related, and one [1] is macroeconomic. Future researches may use these variables and validate significance using statistical methods.
\end{abstract}

Key words: Bank valuation, Bank valuation frameworks, Bank valuation methods, Factors impacting bank valuation, Bank value

JEL classification: C23, G32, G21 Submitted: 04.06.2019 - Accepted: 26.06.2019

\section{Introduction}

The role that banks play in an economy is undeniably important. Banks promote economic wealth, and signify strength of a country's financial system, apart from its responsibility of keeping public trust and confidence (Sinha, Sharma \& Sondhi, 2013). The traditional functions of deposit and loan have evolved into complex practices that banks use to provide financial backbones for an economy. A country's stability is largely dependent on banks because of its: a) ability to maintain resiliency through diversified sources of revenues, assets, and liabilities; b) ability to achieve higher profitability from revenue and cost synergies; c) has greater transparency that helps lower counterparty risks; d) can early detect accumulating systemic risks; and e) can better deal with mismatches in loan-deposits (Schildbach, 2012). However deposits and loans alone are not sufficient to support the financial structure banks should have to support a country's economic needs. Other means of increasing holding of banks on funds have to be made, and one of it is participation in stock markets. Company valuation is one of the many bases by which investors make investment decision, and this is where 
valuation practices become critical. According to Pandey (2015), all assets—whether financial or real-can be valued, but the complexities and the details of valuation will vary from case to case. Valuation is not to be treated solely as an application of valuation models nor a routine exercise, but a practice that is grounded as well on subjective and professional judgment (Organismo Italiano di Valutazione, 2018). This makes valuation essential in making perception-based judgment objective. Given the importance of bank valuation in an economy, this paper reviews scholarly articles on bank valuation practices

Valuation is mostly grounded on assumptions that have the tendency to turn into conventional wisdom, and if the context requires critical thinking when applied (Bini, 2018). The term "value" has made valuation some sort of a philosophical dictum, disguised in the form of complex calculation models, which at some point tend to toggle between over-valued and under-valued judgment. Nevertheless, this literature review is meant not to criticize conflicts that arise from different valuation methods but to provide insights on various valuation practices done around the world. In light of the recent financial shocks that destabilized the credibility of banks and financial institutions, the question, "are banks safe?" fueled more need to critically evaluate soundness of banks in securing and protecting individual, institutional, and national wealth. According to Koller, Goedhart, \& Wessels (2010), banks are complex to value. This arises from the fact that bank's performance are reflected on what is reported and published, and this is mostly from financial reports and accounting decisions taken by the management, however, analysts still have to verify appropriateness of these decisions before making judgment (Koller et al., 2010). Bank's economics relating to credit losses or assets and liabilities mismatch are some of the vital information that analysts may find difficult to determine, forcing them to rely on rough estimates to be utilized for valuation (Koller et al., 2010). Banks are also highly leveraged that makes valuation tend to rely heavily on changing economic situations compared to valuations in other industries (Koller et al., 2010).

Given the importance of bank valuation in economies, the paper reviews prior literatures on bank valuation. The paper is organized as follows: the process of literature review that defines inclusion and exclusion criteria and how the literatures were sourced; literature review that includes importance of bank valuation, bank valuation methods, factors that impact bank valuation, and frameworks for bank valuation; synthesis of the literatures reviewed; and concluding remarks.

\section{Literature Review}

There are two inclusion/exclusion criteria in searching for literatures. First, literatures have to be recent, that is, published over the last ten [10] years (2009 to 2019). Second, only literatures with the terms bank valuation in the title, abstract, or keywords were chosen. Books on valuation and bank valuation were considered as long as the latest published date is within the last 10 years. The best practice for literature review is to search studies in known academic databases (Short, 2009). These databases include Research Gate, Science Direct, Scientific Research Publishing, Google Scholar, Ebsco Host, Kopernius, and Emerald Insight. Moreover, the references used in the literatures reviewed were also examined to add on the inventory of studies available. The use of this literature search strategy led to the identification of thirty-two [32] related studies.

\section{Importance of Bank Valuation}

Bank valuation is significant to shareholders, interested and potential investors, government entities, management, and society at large because safety and profitability of funds are at stake (Gounder and Venkateshwarlu, 2017; Previtali, 2013). Banks that create value represents stability of economic systems, as evidenced by the recent financial crisis on how financial stability is a factor of confidence in banks, and a requisite for a well grounded economic growth (Previtali, 2013). Bank valuation is relevant to policy makers as it examines whether transparency of government bailouts is necessary, as evidenced by the United States' Troubled Assets Relief Package [TARP] that included the Capital Purchase Program [CPP], in the same way bank managers need to assess the impact of accepting government intervention programs $(\mathrm{Ng}$, Vasvari, \& Moerman, 2015). The US government announced that TARP is not a relief program for poorly performing banks and this was met by heavy negative media coverage as the viability of the program and its ability to help the US economy recover during the financial meltdown were questioned ( $\mathrm{Ng}$ et al., 2015). The negative 
media coverage considerably declined stock returns of CPP and non-CPP participating banks, but the decline is more pronounced among CPP participating banks ( $\mathrm{Ng}$ et al., 2015).

Valuation of banks is important because it is not about growth of profit but on growth of stability and value of the bank as well (Eva, 2010). Trust in the banking and financial sectors are fueled by states and their guarantees, and bank failures can significantly cause economic problems (Eva, 2010). The state and other regulatory institutions have an enormous task of analyzing interventions that support the banking and financial markets to prevent recurrence of problems. This translates to a huge role that regulations play in making sure that the objective of growth in stability and value of banks are within the bounds of laws that limit as much risk-taking as possible that confident banks may take in the future. Dermine (2009) explained that fundamental bank valuation models are useful in evaluating banks' interest rate risk because banks are funded in major by deposits with varied maturities - short and longer maturities. Fundamental bank valuation is based on economics and finance principles that allow it to separate liquidation value from franchise value (Dermine, 2009). The model also provided a conceptual framework that help estimate duration of nonmaturing savings and demand deposits (Dermine, 2009).

\section{Bank valuation methods}

The study of Deev (2011) explained that the common valuation methods are: asset-based or accounting valuation, market or relative valuation, income approach or appropriately known as discounted cash flow valuation, and contingent claim valuation. Asset-based valuation values the loan portfolio of a bank by deducting outstanding debt from assets, and this method is used liquidation value of bank for legal proceedings (Deev, 2011). But the method is seldom used for multiple businesses entry or entering regions because of the difficulty in its application, however the method is used to justify the value of a bank's intangible assets (Deev, 2011). According to Hrdy (2018), asset-based approach is applicable for valuation of some portion of the bank's business, or for purposes of tax or accounting.

Relative valuation is the simplest method, and according to analysts, this approach is regularly found on business reports (Deev, 2011; Forte, Gianfrate, and Rossi, 2017). Relative valuation determines bank's equity value as a function of chosen fundamentals and average price of the banks' peers (Nissim, 2013). Price-earning ratio $[\mathrm{PER}]$ and price-to-book value ratio $[\mathrm{P} / \mathrm{BV}]$ are the two most useful multiples. According to Forte et al., (2017), relative valuation have a downside on the following: (1) relative valuation is not reliable if there is only one single value driver - and to be useful, combined investigation with other value drivers must be made; (2) the shortcomings of a single value driver is crucial in the financial industry because the link between book value and earnings is considered robust (Nissim, 2010, as cited in Forte et al., 2017); (2) the method may be short-sighted since it is based only on a particular time estimate and does not include nor reflect changes in a firm's business, competition, and features in the market (Schreiner, 2007 as cited in Forte et al., 2017). Relative valuation is suitable when there are banks or transactions that are comparable (Hrdy, 2018).

Income approach use predicted cash flows in the future discounted to the present, and this method is highly utilized in academic research, getting acclaimed for its best theoretical competencies (Deev, 2011). Income approach comes in different methods such as free cash flow on equity [FCFE], and dividend discount model [DDM]. However, some subjectivity on its utility exists because it is dependent on how an analyst foresees the bank's future returns and accompanying risks. According to Hrdy (2018), income approach appears to be highly demanding during strategic analysis and finalization of financial plans but is informative and useful because it takes into account the future of the bank under valuation.

Contingent claim valuation has more complex mathematical tones in it, such as the Black-Scholes-Merton model that takes the function of six variables namely current price of stock, dividend yield, option strike price, risk-free rate during the life of the option, period remaining until option matures, and price volatility of the stock (Deev, 2011). The study of Titko \& Lace (2012) developed a model for valuation of Latvian banks. Among thirty two [32] banks that operate in Latvia, eighteen [18] commercial banks were chosen for the analysis. The study revealed that an alternative mathematical model using regression analysis is probable, apart from existing methods of valuation because it yielded an R-squared $\left[R^{2}\right]$ value that is high at 0.922 or 92.2\% (Titko \& Lace, 2012). The optimal model was expressed in the following equation: 
Dayag \& Trinidad / International Journal of Research in Business and Social Science,

Vol 8 No 4, 2019 ISSN: 2147-4486

\section{Bank value $=2,038 \times$ Provision of doubtful loans $+3,693 \times$ net interest income}

The model, however, involved only financial ratios that are significant, and residual value calculations reveal more than $50 \%$ gap between predicted value using the model and market data, indicating that further research is necessary (Titko \& Lace, 2012).

Velasco \& Wong (2013) made a critical examination of 171 researches on the valuation of some of the largest European banks during the year 2011. The study concluded that there is a large gap between financial literature and real world practice of bank valuation methods. Typically, sell side analysts use similar tools proposed in literatures, however, actual practices show some deviations from literature. First, there is no generic FCFE model probably due to difficulty is predicting free cash flow apart from just the dividend values; second, book value is examined jointly with adjusted book value to take account of intangible assets that some banks possess; and third, dividend yield ratio is evaluated in all research domains but is not even included nor mentioned in literatures (Velasco \& Wong, 2013).

The study of Charoenwong, Maysami \& Ding (2014) empirically compared bank valuation of conventional and Islamic banking in Malaysia. Islamic banking is strictly guided by Shariah principles that prohibit acceptance or payment of interests (or riba) in any financial transaction (Charoenwong et al., 2014). The study analyzed four [4] conventional banks and two [2] Islamic banks in Malaysia following the period 1999 to 2004. Tobin's $Q$ was used as proxy for measuring banks' value and the independent variables are: proportion of bank's total revenue from Islamic banking operations [IsIrev], proportion of independent directors on the board of the bank [Inddir], ROE, logarithm of the total assets of the bank [TA], and bank's leverage ratio. The study showed that even with the non-interest principle adhered to by Islamic banks, it did not exhibit better ROE and leads to decrease bank value (Charoenwong et al., 2014). This implies that Islamic banking have to make some sensitive decisions in as far as bank valuation is concerned. The study of Calomiris \& Nissim (2014) examined the changes in market valuation of banking activities particularly the decline in banks' market-to-book values. The decline is attributed not on the delay in recognition of losses from existing financial instruments, but more on the decline in the intangibles - customer relationships and other intangibles that are related to business opportunities (Calomiris \& Nissim, 2014).

Market-to-book ratio is calculated as the market value of equity divided by tangible common equity (Calomiris \& Nissim, 2014). The sample is composed of all listed US bank holding companies with total assets of more than $\$ 500$ million as of March 2006, and as seen in Fig. 1, market-to-book ratio has not recovered from its pre-financial crisis level as of December 2013.

From the examination of market-to-book ratios, a valuation equation using balance sheets, income statements, and other attributes to determine drivers of bank value. The study's valuation model posited that: (1) banks create intangible assets that are valuable based on the type of assets and liabilities produced (such as loan and deposit relationships), including noninterest income activities (such as underwriting, loan servicing, making markets); (2) streams of noninterest income are heterogeneous, meaning, it varies in profitability and persistence; (3) value is also dependent on other characteristics, such as ability of the bank to signify its value to the market through dividend payments, bank's capital ratio that reflects its choice of capital financing structure, bank size, and the extent to how the bank bears in interest rate risk; and (4) valuation of assets, liabilities, and income streams depending on dynamic market conditions (Calomiris \& Nissim, 2014). 


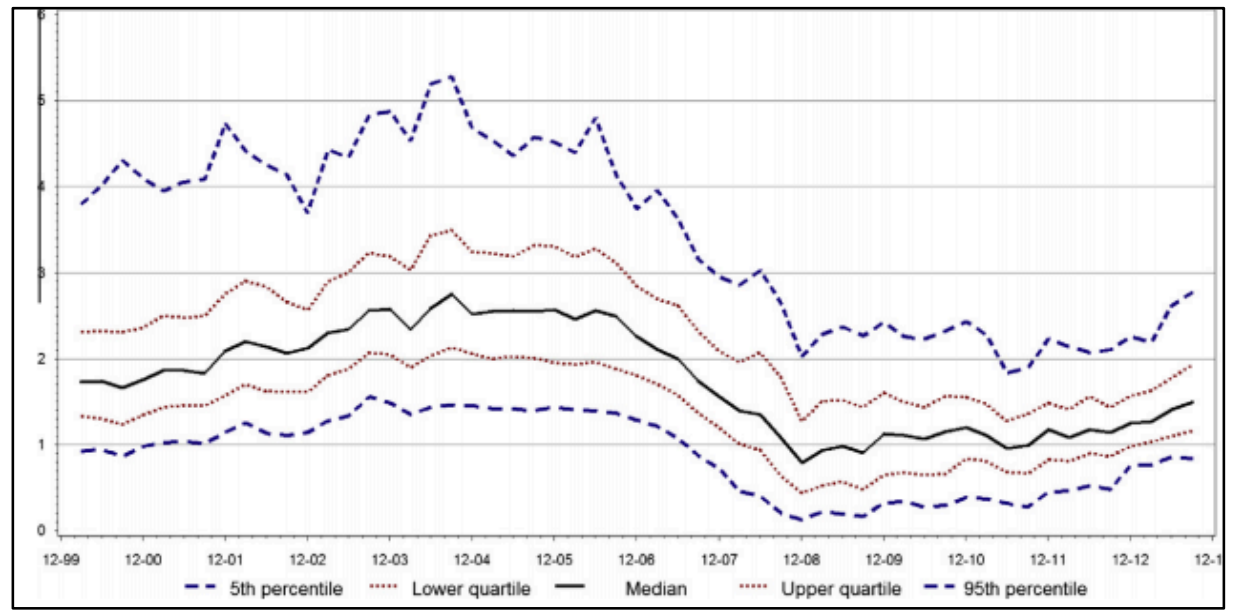

Source: Calomiris \& Nissim, 2014

Figure 1: Trend of market-to-book ratio of large, publicly listed US bank holdings

The study of Massari, Gianfrate, \& Zanetti (2014) offered a type of approach that can be used in the final valuation of banks in which each business that the banks have will be valued separately, then summed up to form the bank's final valuation. The commercial banking arm can be valued using the income approach of discounted cash flow to equity [DCFE]; investment banking can be valued using relative valuation such as price-earnings $[\mathrm{P} / \mathrm{E}]$ multiple; and asset management using price-asset under management [P/AUM] valuation (Massari et al., 2014).

The study of Shaalan (2018) proposed a model for commercial bank valuation using data of listed commercial banks in Bahrain Stock Exchange. The study resulted to identifying independent variables that influence the intrinsic value of commercial banks and these were operational efficiency, bank adequacy, size of assets, and ROE (Shaalan, 2018).

In a seminal work done by Hrdy (2011, as cited in Hrdy, 2018), a method called Bond Pricing Model was recommended for commercial banks valuation, which was basically a combination of income and property method, and follows this equation:

$$
M V=\frac{R O E}{C O E} x N A V
$$

Where: $M V=$ market value of the bank; $R O E=$ return on equity;

$$
\text { COE = cost of equity; } \quad \text { NAV = net adjusted value of assets }
$$

This method is acceptable for commercial bank valuation, however, it does not take into account the future potential of the bank, and results to lower valuation compared to when income approach is used (Hrdy, 2018). This model should be used in conjunction with the income approach so that the future potential of the bank being valued will be considered (Hrdy, 2018).

\section{Factors that Impact Bank Valuation}

The study of Carnevale \& Mazzuca (2014) looked into the impact of sustainability reports on bank valuation. Corporate Social Responsibility [CSR] and sustainability reporting [hence referred to as Sustainability Reports] has been part of Annual Reports that companies make every year, including banks. In fact, the number of banks that report and publish SRs has been increasing yearly (Vigano \& Nicolai, 2009; Van Wensen et al., as cited in Carnevale \& Mazzuca, 2014). Deposit and loan functions of banks do not require the latter to report specifics as to who or where bank deposits are loaned or invested to. Bank's reputation 
has a key role in the fiduciary relationship between the bank and the depositor, meaning CSR is a tool to increase transparency to investors (Carnevale \& Mazzuca, 2014). Using a sample of 176 listed banks in Europe, the study examined if a relationship exists between stock price and SRs, using pooled regression models. The study produced some complex results. In general investors appreciate disclosures indicated in SRs and this has a positive impact on stock prices; however, indirect effects show negative impact on book value per share and effect on earnings per share is not significant (Carnevale \& Mazzuca, 2014). On a crosscountry basis, the value of SR disclosures vary, and this is likely due to different institutional contexts (Carnevale \& Mazzuca, 2014).

Charumathi \& Suraj (2014) applied six [6] valuation models in valuing bank stocks using data from 14 banks listed in Bombay Stock Exchange [BSE] Bankex. The six valuation models are Ohlson's valuation model [EBO], P/B model, P/E model, capital asset pricing model [CAPM], dividend discount model [DDM], and excess returns model. Linear regression with market price as dependent variable and several independent variables - book value [BV] per share, earnings per share [EPS], beta, EPS growth rate, ROE, risk-free [RF] rate, market return $[R m]$, dividends per share, $B V$ of equity, present value $[\mathrm{PV}]$ of excess return, and outstanding shares issued were utilized. The results show that EBO model has the best explanatory power, and were able to capture different aspects of bank stocks' equity values, making the model useful in identifying mispriced securities that yield abnormal returns (Charumathi \& Suraj, 2014). Relative valuation models such as P/B and P/E models also outperformed other models, while CAPM and DDM cannot be relied on (Charumathi \& Suraj, 2014). Among the independent variables used, book value per share is the most significant one that impact bank share prices as evidenced by the EBO and P/B models (Charumathi \& Suraj, 2014).

The study of Guerry \& Wallmeier (2015) considered the impact of diversion on valuation of banks. The study used data from banks listed on the Bureau van Dijk Bankscope database, Thomson Reuters data stream for data on market capitalization, regulatory data from Barth et al., (as cited in Guerry \& Wallmeier, 2015), and financial freedom index from Heritage Foundation, and covered a 16-year period from 1998 to 2016. The period experienced various business cycles and stock market conditions. Using panel data regression analysis, there are two main findings of the study: diversification discount in valuation of banks based on past studies declined before the financial crisis, and completely disappeared after the crisis; and banks' market valuation respective of size and diversification is well aligned internationally (Guerry \& Wallmeier, 2015). The implication of the study is, substantial diversification discount suggested by past studies, that is overestimated diversification synergies and under estimated agency costs, leads to inefficient business combinations, particularly in banking (Guerry \& Wallmeier, 2015). The study reveals that diversification is neutral with regards to value creation - does not add nor destroy value.

The relationship between bank valuation and non-interest income was studied by Li \& Feng (2015). The interest in this study arose due to the increasing share of non-interest income [NII] as a share of net operating revenue [NOR] (see Fig. 2). In 1984, the share of NII was $10 \%$ and by 2015 , it has reached $35 \%$

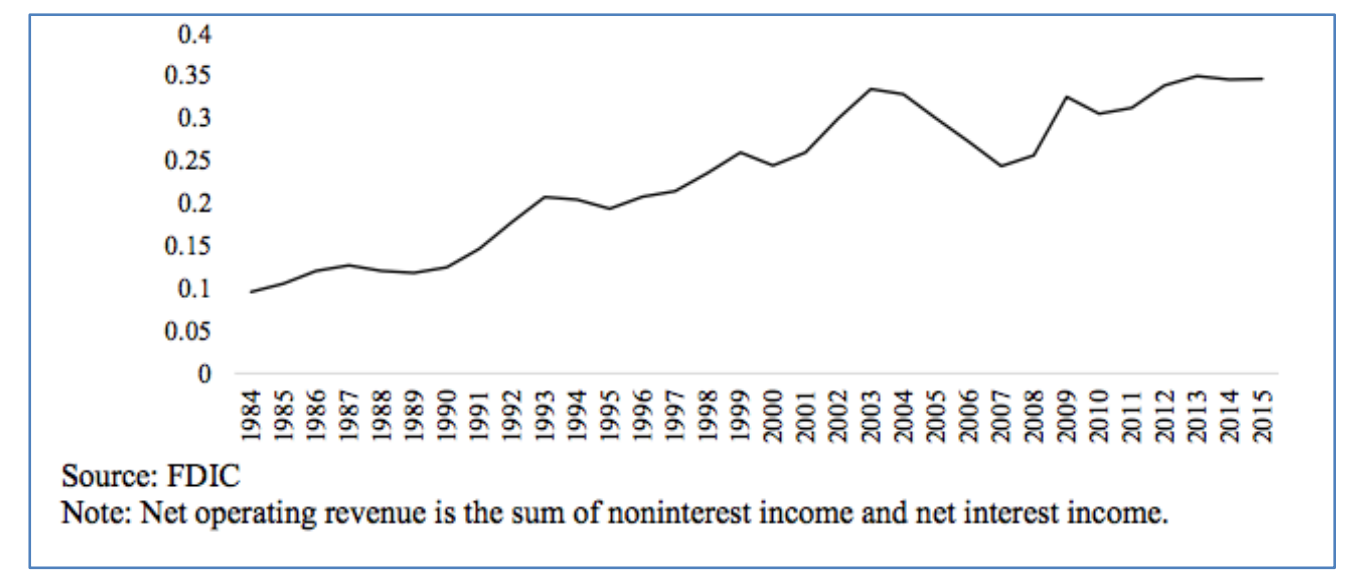

Figure 2: Non-interest income as a share of net operating revenues 
Non-interest income decreases the volatility of banks and it is important that banks reduce risk, and it is justifiable that regulators decrease capital requirements because it becomes an incentive for banks to generate more non-interest income since it is less risky (Li \& Feng, 2015). Using Tobin's $Q$ and market-tobook ratio to measure valuation, the study used 625 U.S. bank holding companies from 2003 to 2015, and conducted regression of variables that include bank size, capital ratio, loans to assets ratio, deposits to asset ratio, and return to equity (Li \& Feng, 2015). The samples were divided into three groups: prior to financial crisis (2003 -2006), during financial crisis (2007 - 2009), and post financial crisis $(2010-2015)$, and these groupings were based on the definition of financial period made by Bouman (2013 as cited in Li \& Feng, 2015). The study showed that noninterest income is positively correlated to valuation of large banks in all of the three periods; positively correlated to valuation of medium sized banks during and post financial crisis, and positively correlated to valuation of small sized banks after the financial crisis (Li \& Feng, 2015). The implication is, large banks have more noninterest income gained from experience and availability of technology is more pronounced compared to small and medium sized banks. This means, large banks are increasing its noninterest income since the implementation of Dodd-Frank Act of 2010 made it more difficult for banks to engage in service mortgage loans (Li \& Feng, 2015). Moreover, the Volcker Rule stipulated in the Dodd-Frank Act of 2010 is now prohibiting banks from engaging in proprietary trading to generate revenues, and a ceiling was set for investments in hedge funds and private equity (Li \& Feng, 2015).

The study of Egan, Lewellen, \& Sunderam (2016) looked into determinants of creating value among US commercial banks focusing on deposit productivity and asset productivity. Using data of eight hundred fortyseven [847] bank holding companies from 1994 to 2015 taken from the Federal Reserve FR Y-9C reports for balance sheets and income statements, stock market data from CRSP, advertised deposit rates from RateWatch, and branch-level deposit quantities from FDIC annual summary of deposits, productivity measures were calculated using demand estimates, and residuals and bank fixed effects to measure asset productivity (Egan et al., 2016). The study showed that banks create value through excellent deposit gathering, outstanding production of loans and other assets, and forming synergies between loans and deposits; and among these three, the ability to produce deposits is the most significant in explaining crosssectional changes in bank value (Egan et al., 2016). Moreover, the study concluded that banks are unique entities that create value through provision of special services from their liabilities (Egan et al., 2016). Gounder \& Venkateshwarlu (2017) compared residual income model and relative valuation model using panel data regression analysis of twenty four [24] public sector banks and sixteen [16] private sector banks in India. The empirical results show that residual income model is better than relative valuation model in terms of measuring bank shareholder value (Gounder \& Venkateshwarlu, 2017). A positive and significant relationship was found between banks' intrinsic value using residual income model and market price of banks' share using correlation and regression tools (Gounder \& Venkateshwarlu, 2017).

The study of Bertsatos, Sakellaris \& Tsionas (2017) examined the impact of the financial crisis on the valuation of large, systemic bank holding companies in the US, using the 3DM of Bertsatos \& Skellaris (2016 as cited in Bertsatos et al., 2017). 3DM stands for Dynamic Dividend Discount Model. According to the 3DM framework, an equilibrium exists between price-to-book $[\mathrm{P} / \mathrm{B}]$ ratio and cost of equity predicted growth of net income, and modified dividend payout ratio (Betsatos et al., 2017). Using the pooled mean group method, a method found by Pesaran et al., (1999 as cited in Bertsatos et al., 2017) that allows P/B ratio to deviate from the equilibrium temporarily. The study found evidence that the financial crisis did not alter investors' attitude towards the characteristics of banks (Bertsatos et al., 2017). For example, before and after the crisis, investors in large, systemic bank holding companies penalized leverage although it is temporary (Bertsatos et al., 2017). He \& Niu (2017) examined the impact of economic policy uncertainty [EPU] on valuation of banks. Using Tobin's $Q$ to measure valuations, the study sampled quarterly observations on publicly traded banks in the US from first quarter of 1990 to fourth quarter of 1995. The study showed that EPU negatively impacts bank valuation, and the negative effect is more distinct on banks with high ratio of loans to total assets (He \& Niu, 2017).

Song (2017) studied how accounting regulations in banking affect bank valuation and volatility. Using data on accounting regulations and bank stock volatility of 35 countries, the study revealed that bank stocks' 
valuation are higher and with lower volatility in countries that practice more stringent regulations on the quality of external audits and financial statements transparency (Song, 2017).

An understanding on the difference between book and market measures of bank leverage through disaggregation of the drivers of market value of equity of banks [MVE] with book value of equity [BVE] into components of value of franchise and value of government guarantees was researched by Atkseon, d'Avernas, Esifeldt, \& Weill (2019). The framework was tested in US banks, and the model suggests that efforts to ease regulatory burden on banks moving forward should be exercised with caution because government guarantees' value on bank equity is highly susceptible to minute changes in bank assets' risk exposure (Atkeson et al., 2019). The implication is, significant increases in bank valuation are foreseen if regulators allow even moderate increase in risk taking by banks (Atkeson et al., 2019). As a result the increase in bank valuation and accounting profitability can be a tempting interpretation of restoration of bank franchise value that was historically damaged by regulation (Atkeson et al., 2019). It should be looked instead as a possible history repeating itself when taxpayers' money had to bail out banks in crisis (Atkeson et al., 2019).

\section{Frameworks for Bank Valuation}

Eva (2010) argued there is no unique, common framework for bank valuation, and from this perspective, there are open possibilities to discover different approaches in measuring value of banks and related financial institutions. Merton (1973 as cited in Eva, 2010) posited the risk-neutral valuation for financial assets that use the value of call option can be related to bank assets' value; Damodaran (2002 as cited in Eva, 2010) said that fundamental valuation rules can be applied as well in financial service institutions; while Koch, Samuelson, Klein \& Monti (2005 as cited in Eva, 2010) developed the theory about the positive relationship between relative market power of banks and net income. Isidro \& Grillo (2012), developed a valuation framework which was an expansion of a bank-specific model by Ohlson (1995 as cited in Isidro \& Grillo, 2012) that was based on two basic activities of banking: deposits and loans. This model's framework was expanded, using banks in the Eurozone as samples, to include off-balance sheet businesses, financial services selling that generate income from fees, and investment and trading in proprietary securities (Isidro \& Grillo, 2012). The empirical analysis also found that sale of financial services for fees is the most significant value-creating activity for Eurozone banks, especially the smaller ones (Isidro \& Grillo, 2012). Moreover, investment and trading yield positive net present value activity for banks, while off-sheet balances contribute to unrecorded goodwill through streams of predicted future income from fees (Isidro \& Grillo, 2012).

The study of Sinha et al., (2013) used the Black Scholes Option Pricing framework on twenty-one [21] public and private banks in India during the period 2003 to 2012. The Black-Scholes-Merton model incorporated bank assets' riskiness with market valuation, since riskiness is one of the components of bank valuation, the other being equity (Sinha et al., 2013). The model reveals that market values underestimate the enterprise value because of risk that is integrated in the market valuation (Sinha et al., 2013). Moreover, asset volatility in private banks is three [3] to five [5] times higher than public banks, putting these banks in high risk level of bank failure on capital adequacy (Sinha et al., 2013). As an implication, regulations require banks to intensify efforts in reducing non-performing assets (Sinha et al., 2013).

The study of Aggelopoulos (2017) developed a framework on bank valuation using two of the generally used and accepted valuation models for banks - discounted equity cash flow and residual income model. The main basis would be financial statements, particularly Balance Sheets and Income Statements as proposed by Dermine (2009 as cited in Aggelopoulos, 2017). The study showed the accounting statements for valuation purposes covering an eight-year analytical period that include balance sheet (see Appendix 1), calculation of risk-weighted assets [RWA] and total regulatory capital (see Appendix 2), statement of change in equity (see Appendix 3), income statement (see Appendix 4), and calculation of equity using free cash flow equity [FCFE] (see Table 1) and residual income [RI] (See Table 2). 
Dayag \& Trinidad / International Journal of Research in Business and Social Science,

Vol 8 No 4, 2019 ISSN: 2147-4486

Table 1: Calculation of Equity Value using FCFE

\begin{tabular}{|c|c|c|c|c|c|c|c|c|c|}
\hline & $1 *$ year & $2^{*}$ year & $3^{\circ}$ year & $4^{*}$ year & $5^{*}$ year & $66^{*}$ year & $7 *$ year & $88^{*}$ year & $9 *$ year \\
\hline Net Income & 112 & 115 & 119 & 122 & 126 & 130 & 134 & 138 & 142 \\
\hline (+) Depreciation & 9 & 9 & 10 & 10 & 10 & 10 & 11 & 11 & 11 \\
\hline (-) Net Increase in Loans & 105 & 108 & 111 & 115 & 118 & 122 & 125 & 129 & 133 \\
\hline (-) Net Increase in Securities and Investments & 10 & 10 & 10 & 10 & 10 & 10 & 10 & 10 & 20 \\
\hline$(-)$ Net Increase in Amounts due from Banks & 12 & 12 & 12 & 12 & 12 & 12 & 12 & 12 & 22 \\
\hline (-) Net Capital Expenditure & 14 & 15 & 15 & 16 & 16 & 17 & 17 & 18 & 18 \\
\hline (+) Net Increase in Deposits & 95 & 97 & 100 & 103 & 106 & 110 & 113 & 116 & 120 \\
\hline (+) Net Increase in Interbank Funds & 35 & 28 & 29 & 29 & 29 & 30 & 30 & 30 & 49 \\
\hline Equity Cash Flow & 109 & 106 & 109 & 112 & 115 & 119 & 122 & 126 & 129 \\
\hline \multicolumn{10}{|c|}{ Robustness check for the calculation of FCFE (second method, Koller Goedhart and Wessels, 2005 [1]) } \\
\hline (+) Dividends and Potential divldends & 109 & 106 & 109 & 112 & 115 & 119 & 122 & 126 & 129 \\
\hline (-) Share Capital Issue (Repurchase) & $\cdot$ & * & * & $\cdot$ & $\cdot$ & $\cdot$ & $\cdot$ & - & $\cdot$ \\
\hline Equity Cash Flow (ECF) & 109 & 106 & 109 & 112 & 115 & 119 & 122 & 126 & 129 \\
\hline Present Value of ECF & \multicolumn{8}{|c|}{$99^{*}(0.909) * 87(0.826) 82(0.751) 77(0.683) 72(0.621) 67(0.565) 63(0.513) 59(0.466)$} & \\
\hline Terminal Value & $\cdot$ & $\cdot$ & $\cdot$ & $\cdot$ & $\cdot$ & $\cdot$ & $\cdot$ & $\cdot$ & $1420 * * *$ \\
\hline Present value of Terminal Value & * & . & * & . & - & * & . & * & $662 * \cdots(0.424) *$ \\
\hline \multicolumn{10}{|c|}{ EQUTTY VALUE: Present Value of ECF + Present Value of terminal value $=605+662=1267$} \\
\hline
\end{tabular}

Source: Aggelopoulos, 2017

Table 2: Calculation of Equity Value using PRIM

\begin{tabular}{|c|c|c|c|c|c|c|c|c|c|}
\hline & $\underline{1^{*} \text { year }}$ & $\underline{2^{*} \text { year }}$ & $3^{\circ}$ year & $4^{\circ}$ year & $5^{*}$ year & $6^{\circ}$ year & $\underline{7^{*} \text { year }}$ & $\underline{8^{*} \text { year }}$ & $9^{*}$ year \\
\hline Net Income & 112 & 115 & 119 & 122 & 126 & 130 & 134 & 138 & 142 \\
\hline $\begin{array}{l}\text { (-) Cost of the Capital Employed } \\
\text { (Equity b.o.y. * Cost of Equity 10\%) }\end{array}$ & 33 & 33 & 34 & 35 & 36 & 38 & 39 & 40 & 41 \\
\hline Residual Income & 79 & 82 & 85 & 87 & 90 & 92 & 95 & 98 & 101 \\
\hline Present Value of Residual Income & $72^{*}(0.909)^{* *}$ & $68(0.826)$ & $64(0.751)$ & $60(0.683)$ & $56(0.621)$ & $52(0.565)$ & $49(0.513)$ & $46(0.466)$ & - \\
\hline Terminal Value & - & - & - & - & - & - & - & - & $1010^{* * *}$ \\
\hline Present Value of Terminal Value & - & - & - & - & - & - & - & - & $471^{* * * *}(0.4241)^{* *}$ \\
\hline
\end{tabular}

Source: Aggelopoulos, 2017

An important framework for bank valuation is regulation. According to a recent publication issued by the Bank for International Settlements [BIS], regulation for banks is more strict compared to corporations (BIS, 2018). It is mandatory for banks to keep predefined capital adequacy ratios based on book value of equity, since book values are more meaningful value measures for financial firms compared to non-financial companies (BIS, 2018). Moreover, accounting practices are essential in bank valuations because assets held by banks are usually in the form of financial instruments, with majority of these assets are reported using amortized cost (BIS, 2018). Bank assets are heavily exposed to credit and other related risks, and according to Huizinga and Laeven, 2012 (as cited in BIS, 2018), delayed recognition of losses have been significant factors for US banks because of the recent financial meltdown especially with regards to exposures to mortgage markets. The combination of book-based valuation metrics, for one, the price-to-book ratios [PBRs], and market-based valuation measures give useful information for bank valuation (BIS, 2018).

\section{Synthesis}

Previous approaches in bank valuation such as accounting valuation, relative valuation, discounted cash flow, and contingent claim valuation (Deev, 2011; Forte et al., 2017; Nissim, 2013; Hrdy, 2018) are still relevant at present. New approaches have emerged as well such as Titko \& Lace's (2012) bank value using provision for doubtful loans and interest income, Calomiris \& Nissim's (2014) bank value from market-to-book examination, summation of independent valuation of each business arm of banks by Massari et al., 2014, Ohlson's valuation model, and Bond pricing model by Hrdy (2011: 2018). These valuation models looked at individual characteristics of banks that include bank size, sustainability reports, total assets, ratio of loans to 
assets, business diversification, non-interest income, and other related factors that influence bank value. In all of these valuation models, it is observed that banks have more conservative approach in risk taking. The literatures also revealed that the impact of the global financial crisis was deeper than it was anticipated, and this has kept volatility of banks stocks' prices still in crucial states in most stock market exchanges. On the other hand, the importance of banks, in reference to other financial institutions, is still upheld in terms of economic growth and development. Banks still remain as the top financial backbone of any economy. Frameworks also became important bases of bank valuation. The emergence of varied frameworks where valuation could be based arose, confirm the postulate made by Eva (2010) that there is no unique framework for bank valuation, and each has to be developed depending on each bank's scenario. Some of the new frameworks that came out from the literature review were inclusion of off-sheet bank businesses, financial services selling that generate income from fees, and investment and trading in proprietary securities in the standard framework of loans and deposits (Isidro \& Grillo, 2012) that are applicable to Eurozone banks; the use of Black Scholes Option Pricing framework on banks in India (Sinha et al., 2013); and the framework developed by Aggelopoulos (2017) using balance sheets, risk-weighted assets, and regulatory capital. The Bank for International Settlements also recognized addition of regulatory framework in bank valuation.

The combination of bank valuation frameworks and new models that have emerged can be good subjects for further research by academicians and practitioners. The most crucial in any bank valuation model would be accounting practices since banks hold assets that are not entirely their own. Trust and confidence in these accounting practices can uphold and at the same time break down any value created by banks. Islamic banking is also another interesting subject for research because a dearth of studies on value drivers for this type of banking is observed. Value drivers also varied based on the literature review. Fig. 3 summarizes the different value drivers identified by various sources based on bank type.

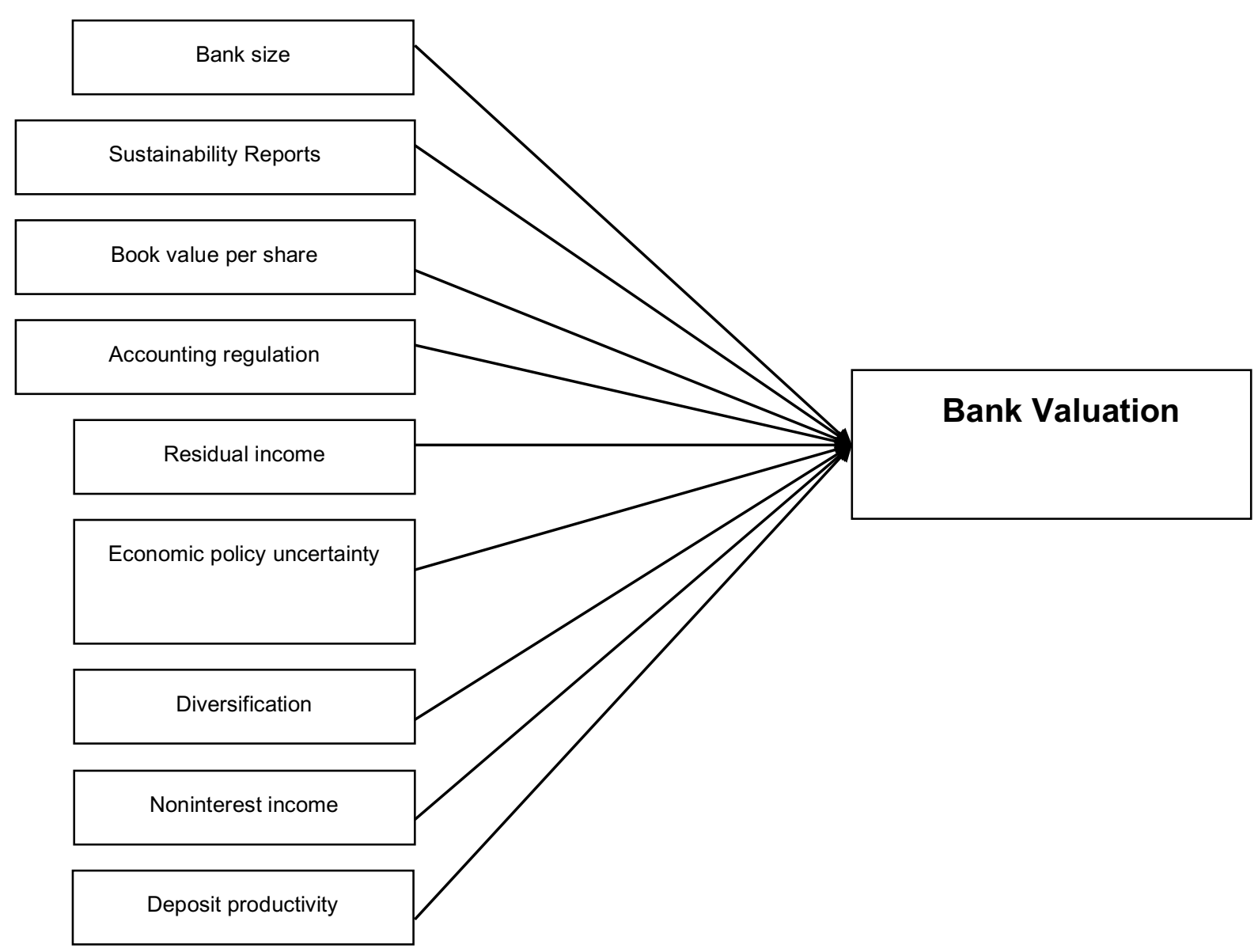

Figure 3: Value drivers of bank valuation derived from the literature review 
Fig. 3 represents a condensation of significant factors (or variables) that literatures identified to be influencing bank valuation. Among the nine [9] factors, seven [7] are found to be firm-specific, one [1] is regulationrelated, and 1 is macroeconomic. These are variables recommended for future researches to validate using statistical methods to confirm if the assumptions hold true using proxy data. Identification of indicators for these variables, however, can be a challenge, like for example, what would be a measure of accounting regulation, or economic policy uncertainty. This is crucial especially in the performance of regression or correlation analysis.

\section{Conclusions}

Bank valuation remains to be an intricate process that was made even more complex by the attempt to be risk averse stemming from lessons learned in the global financial crisis. Although most banks were resilient, these institutions have become careful in its risk taking initiatives, taking measures to be transparent and conservative in all its transactions. This is to protect mainly the depositors and depositors, and largely the stakeholders. The basic loan and deposit functions are now disaggregated on specific characteristics of products and services, so that practices will be focused on reducing risk and increasing returns on these offerings. For example deposit functions are considered to be of two types - nonmaturing such as demand deposits, and maturing such as time deposits, and bonds. These characteristics have different value character and magnitude. Other bank offerings such as noninterest products have also contributed to increase in bank value, which means, banks have to give more importance to these products as well. Investors still prefer banks under tight regulation and scrutiny because it lowers down volatility. In all respects, bank valuation remains to be an active research topic due to the dynamic nature of the banking system and changing economic situations. Moreover, sustainability practices are getting the attention of investors, and this adds value to the bank. As mentioned, bank valuation is a continuously evolving process and as long as banks play significant roles in economic systems, new methods and theories of valuation need to arise to keep up with the highly dynamic global world. For instance, over-the-counter transactions are slowly being replaced by online banking, and virtual currencies are now being utilized on many exchange transactions. This may ultimately affect value creation in banks, and may require thorough review of existing practices' applicability on the rising new modes of transactions. Bank valuation may also be of interest to private investors since most banks are publicly listed in stock exchanges. Understanding value drivers of banks can assist investors in making investment decisions that will benefit both the bank and the investors.

\section{References}

Aggelopoulos, E. (2017). Understanding bank valuation: an application of the equity cash flow and the residual income approach in bank financial accounting statements. Open Journal of Accounting, 06(01),1-10. http://dx/doi.org/10.4236/ojacct.2017.61001

Atskeon, A.G., d'Avernas, A., Esifeldt, A.L., \& Weill, P.O. (2019). Government guarantees and the valuation of American bnks. Department of Economics, UCLA. Retrieved from http://www.adriendavernas.com/papers/valuationofbanks.pdf

Bank for International Settlements. (2018). Bank valuation and price-to-book ratios. BIS Quarterly Review. Retrieved from https://www.bis.org/publ/qtrpdf/r_qt1803x.htm

Bertsatos, G., Sakellaris, P., \& Tsionas, M. (2017). Did the financial crisis affect the market valuation of large, systemic US banks? Journal of Financial Stability, 32, 115-123

Bini, M. (2018). Implied use of cost of capital: how to calculate it and how to use it. Wolters Kluwer Italia.

Calomiris, C.W., \& Nissim, D. (2014). Crisis-related shifts in the market valuation of banking activities. Journal of Financial Intermediation, 23, 400-435. http://dx/doi.org/10.1016/j.jfi.2014.05.002

Carnevale, C., \& Mazzuca, M. (2014). Sustainability report and bank valuation: evidence from European stock markets. Business Ethics: A European Review, 23(1), 69-90. https://doi.org/10.1111/beer.12038 
Dayag \& Trinidad / International Journal of Research in Business and Social Science,

Vol 8 No 4, 2019 ISSN: 2147-4486

Charoenwong, C., Maysami, R.C., \& Ding, D. (2014). Bank valuation in Malaysia: an empirical comparison of conventional and interest-free (Islamic) banking models. Journal of International Business Research and Practice, 8, 96-102

Charumathi, B., \& Suraj, E.S. (2014). Comparing stock valuation models for Indian bank stocks. International Journal of Accounting and Taxation, 2(2), 111-127

Deev, O. (2011). Methods of bank valuation: a critical overview. Financial Assets and Investing, 3, 33-44

Dermine, J. (2009). Bank valuation: with an application to the implicit duration of non-maturing deposits. INSEAD, 1-44

Eva, H. (2010). Methods of bank valuation. Economic Analysis, 43(1-2), 50-60

Egan, M., Lewellen, S., \& Sunderam, A. (2016). The cross section of bank value. Harvard Business School. Retrieved from http://people.hbs.edu/asunderam/bank_productivity_20161110.pdf

Forte, G., Gianfrate,G., \& Rossi, E. (2017). Does relative valuation work for banks? Global Finance Journal, 1-41. http://dx.doi.org/10.1016/j.gfj.2018.09.002

Gounder, C.G., \& Venkatechwarlu, M. (2017). Bank valuation models - a comparative analysis. Accounting \& Finance Research, 6(3),116-134. http://dx.doi.org/10.5430/afr.v6n3p116.

Guerry, N., \& Wallmeier, M. (2017). Valuation of diversified banks: new evidence. Journal of Banking and Finance, 80, 203-214. http://dx.doi.org/10.1016/j.bankfin.2017.04.004

He, Z., \& Niu, J. (2017). The effect of economic policy uncertainty on bank valuations. Applied Economic Letters, 1-4. http://dx.doi.org/10.1080/13504851.2017.1321832

Hrdy, M. (2018). Valuation standards for commercial banks in the financial theory and their analysis. Prague Economic Papers, 27(5), 541-553. http://dx.doi.org/10.18267/j.pep.661

Isidro, H., \& Grillo, D. (2012). Value driving activities in Eurozone banks. European Accounting Review, 21(2), 297-341. http://dx.doi.org/10.1080/09638180.2011.585790

Koller, T., Goedhart, M., \& Wessels, D. (2010). Valuation: Measuring and managing the value of companies. Hoboken New Jersey: John Wiley \& Sons

Li, M., \& Feng, T. (2015). Relationship between noninterest income and bank valuation: evidence from the U.S. bank holding companies. Masteral Thesis published in Semantics Scholar. Retrieved from https://pdfs.semanticscholar.org/37d6/6cb986c125dc017ab3059319bb83439ed767.pdf

Massari, M., Gianfrate, G., \& Zanneti, L. (2014). The valuation of financial companies, tools and techniques to value banks, insurance companies, and other financial institutions. London: Wiley \& Sons, printed by TJ International LTD in Great Britain

Nissim, D. (2013). Relative valuation of U.S. insurance companies. Review of Accounting Studies, 18(2), 324-359

Ng, J., Vasvari, F.P., \& Moerman, R.W. (2015). Media coverage and stock market valuation of TARP $\begin{array}{llll}\text { participating banks. European Accounting Review, } & \text { 1-26. }\end{array}$ http://dx.doi.org/10.1080/09368180.2015.1029505

Organismo Italiano di Valutazione. (2018). Presentation of the Journal. Business Valuation OIV Journal, O(0), 3-4, Wolters Kluwer Italia

Pandey, A. (2015). Earnings per share or book value: superior value driver in equity valuations. IIMS Journal of Management Science, 6(1), 1-8

Previtali, D. (2013). Valuation methods and banks' takeover premium: an empirical investigation across the financial crisis 2007. Aidea Conference - Leece Proceedings 
Dayag \& Trinidad / International Journal of Research in Business and Social Science,

Vol 8 No 4, 2019 ISSN: 2147-4486

Shaalan, T. (2018). Proposed model for forecasting the intrinsic value of commercial applied to commercial banks listed on the Bahrain Stock Exchange. Accounting and Finance Research, 7(4), 91-97. https://doi.org/10.5430/afr.v7n4p91

Schildbach, J. (2012). Universal banks: optimal for clients and financial stability. Deutsche Bank Research. Retrieved from https://www.dbresearch.com/PROD/RPS_ENPROD/PROD0000000000455298/Universal_banks\%3A_Optimal_for_clients_and_financial.PDF

Short, J. (2009). The art of writing a review article. Journal of Management, 35, 1312-1317.

Sinha, P.,Sharma, S., \& Sondhi, K. (2013). Market valuation and risk assessment of Indian banks using Black-Scholes-Merton Model. MPRA Paper, 2, 1-25.

Song, L. (2017). The effect of accounting regulations on stock valuation and volatility: evidence from banking industry. Journal of International Financial Management \& Accounting, 28(2), 205-229. http://dx.doi.org/10.1111/jifm.12065

Titko, J., \& Lace, N. (2012). Valuation model for Latvian Banks. $7^{\text {th }}$ International Scientific Conference "Business \& Management 2012" May 10-11, 2012, Vilnius Lithuania, 241-247. http://dx.doi.org/10.3846/bm.2012.032

Velasco, J.L., \& Wong, K.M. (2013). Literature vs. Reality: Bank valuation methods used by equity analysts. NYSEA Proceedings, 6, 221-230 
Dayag \& Trinidad / International Journal of Research in Business and Social Science,

Vol 8 No 4, 2019 ISSN: 2147-4486

\section{Appendix}

Appendix 1: Balance sheet for valuation purposes

\begin{tabular}{|c|c|c|c|c|c|c|c|c|c|c|}
\hline Assets & $\underline{0 \text { (today) }}$ & $\underline{1^{*} \text { year }}$ & $2^{*}$ year & $\underline{3^{*} \text { year }}$ & $\underline{4^{*} \text { year }}$ & $\underline{5^{\circ} \text { year }}$ & $66^{\circ}$ year & $\underline{7^{*} \text { year }}$ & $8^{*}$ year & $\underline{9^{\circ} \text { year }}$ \\
\hline Cash & 100 & 100 & 100 & 100 & 100 & 100 & 100 & 100 & 100 & 100 \\
\hline Balances with Central Bank & 63 & 65 & 67 & 69 & 71 & 73 & 75 & 77 & 80 & 82 \\
\hline Due from Banks & 350 & 360 & 370 & 380 & 390 & 400 & 410 & 420 & 430 & 450 \\
\hline Securities and Investments & 350 & 360 & 370 & 380 & 390 & 400 & 410 & 420 & 430 & 450 \\
\hline Loans (net) & 3500 & 3605 & 3713 & 3825 & 3939 & 4057 & 4179 & 4305 & 4434 & 4567 \\
\hline Fixed Tangible Assets & 175 & 180 & 186 & 191 & 197 & 203 & 209 & 215 & 222 & 228 \\
\hline TOTAL Assets & 4538 & 4670 & 4806 & 4945 & 5087 & 5233 & 5383 & 5537 & 5695 & 5877 \\
\hline \multicolumn{11}{|l|}{ LIABILITIES } \\
\hline Due to Banks & 1059 & 1094 & 1122 & 1151 & 1180 & 1209 & 1239 & 1268 & 1299 & 1348 \\
\hline Customer Deposits & 3150 & 3245 & 3342 & 3442 & 3545 & 3652 & 3761 & 3874 & 3990 & 4110 \\
\hline Bonds Issued & - & . & . & - & - & . & & - & & \\
\hline Other Liabilities & . & . & . & . & . & . & . & . & . & . \\
\hline Total Shareholder Equity & 329 & 332 & 341 & 352 & 362 & 373 & 384 & 395 & 406 & 419 \\
\hline Total Liabilities and Equity & 4538 & 4670 & 4806 & 4945 & 5087 & 5233 & 5383 & 5537 & 5695 & 5877 \\
\hline
\end{tabular}

Source: Aggelopoulos, 2017

Appendix 2: Calculation of risk-weighted assets and regulatory capital

\begin{tabular}{|c|c|c|c|c|c|c|c|c|c|}
\hline & $\underline{1^{*} \text { year }}$ & $\underline{2^{*} \text { year }}$ & $3^{*}$ year & $\underline{4^{*} \text { year }}$ & $\underline{5^{*} \text { year }}$ & $6^{\circ}$ year & $\underline{7^{*} \text { year }}$ & $8^{*}$ year & $\underline{9^{*} \text { year }}$ \\
\hline Risk Weighted Assets (RWA)* & 3316 & 3415 & 3516 & 3619 & 3726 & 3835 & 3948 & 4063 & 4193 \\
\hline $\begin{array}{l}\text { Tier } 1(8 \%) \text { for the Minimum Required Capital and } \\
\text { Additional Capital ( } 2 \%) \text { for Growth Purposes }\end{array}$ & $10 \%$ & $10 \%$ & $10 \%$ & $10 \%$ & $10 \%$ & $10 \%$ & $10 \%$ & $10 \%$ & $10 \%$ \\
\hline Total Regulatory Capital & 332 & 341 & 352 & 362 & 373 & 384 & 395 & 406 & 419 \\
\hline
\end{tabular}

Source: Aggelopoulos, 2017

Appendix 3: Change in equity

\begin{tabular}{|c|c|c|c|c|c|c|c|c|c|}
\hline Years & $\underline{1^{\prime} \text { year }}$ & $2{ }^{\circ}$ year & $3^{*}$ year & $4^{*}$ year & $5^{\circ}$ year & 6 year & $7 *$ year & $8^{\circ}$ year & $99^{*}$ year \\
\hline Equity (Beginning of the Year) & 329 & 332 & 341 & 352 & 362 & 373 & 384 & 395 & 406 \\
\hline (+) Share Capital Increase & - & - & - & - & $\cdot$ & $\cdot$ & $\cdot$ & $\cdot$ & . \\
\hline (+) Profit for the Period (from Table 4) & 112 & 115 & 119 & 122 & 126 & 130 & 134 & 138 & 142 \\
\hline (-) Dividends and Potential Dividends & 109 & 106 & 109 & 112 & 115 & 119 & 122 & 126 & 129 \\
\hline Equity (End of Year) (as It Is Derived from the Above Table) & 332 & 341 & 352 & 362 & 373 & 384 & 395 & 406 & 419 \\
\hline
\end{tabular}

Source: Aggelopoulos, 2017

Peer-reviewed Academic Journal published by SSBFNET with respect to copyright holders. 
Dayag \& Trinidad / International Journal of Research in Business and Social Science, Vol 8 No 4, 2019 ISSN: 2147-4486

Appendix 4: Income statement for valuation purposes

\begin{tabular}{|c|c|c|c|c|c|c|c|c|c|c|}
\hline & $\underline{0 \text { (present) }}$ & $\underline{1^{\circ} \text { year }}$ & $\underline{2^{*} \text { year }}$ & $3^{*}$ year & $\underline{4^{*} \text { year }}$ & $\underline{5^{*} \text { year }}$ & $6^{*}$ year & $\underline{7 *}$ year & $8^{*}$ year & $9^{\circ}$ year \\
\hline Interest and Similar Income & 77 & 79 & 82 & 84 & 87 & 89 & 92 & 94 & 97 & 101 \\
\hline (+) Fee and Commissions Income & 15 & 16 & 16 & 17 & 17 & 18 & 18 & 19 & 19 & 20 \\
\hline (t) Other Operating Income & 8 & 8 & 8 & 8 & 9 & 9 & 9 & 9 & 10 & 10 \\
\hline Total Operating Income & 100 & 103 & 106 & 109 & 113 & 116 & 119 & 123 & 126 & 130 \\
\hline (-) Depreciation & 9 & 9 & 9 & 10 & 10 & 10 & 10 & 11 & 11 & 11 \\
\hline (-) Other General Administrative Expenses & 61 & 63 & 65 & 67 & 69 & 71 & 73 & 75 & 77 & 80 \\
\hline (-) Provision for Impairment & 25 & 26 & 27 & 27 & 28 & 29 & 30 & 31 & 32 & 33 \\
\hline Profit before Tax & 145 & 149 & 154 & 159 & 163 & 168 & 173 & 178 & 183 & 189 \\
\hline$(-)$ Income Tax & 36 & 37 & 38 & 40 & 41 & 42 & 43 & 45 & 46 & 47 \\
\hline Net Profit & 109 & 112 & 115 & 119 & 122 & 126 & 130 & 134 & 138 & 142 \\
\hline
\end{tabular}

Source: Aggelopoulos, 2017 